\title{
$\mathrm{Al}$ 합금과 $\mathrm{STD} 61$ 강의 소착에 미치는 첨가원소 $\mathrm{Fe}, \mathrm{Mn}$ 의 영향
}

\author{
김유미***† · 홍성길* - 최세원** · 김영찬** - 강창석** \\ *전남대학교, **한국생산기술연구원
}

\section{Effects of Fe, Mn Contents on the Al Alloys and STD61 Steel Die Soldering}

\author{
Yu-Mi Kim***†, Sung-Kil Hong*, Se-Weon Choi**, Young-Chan Kim** and Chang-Seog Kang** \\ *Chonnam National University, 77 Yongbong-ro, Buk-gu, Gwangju 500-757, Korea \\ **KITECH, 1110-9 Oryong-dong, Buk-gu, Gwangju 500-480, Korea
}

(2012년 2월 21일 접수 : 2012년 3월 16일 최종수정 : 2012년 3월 19일 채택)

\begin{abstract}
Recently, various attempts to produce a heat sink made of Al 6xxx alloys have been carried out using die-casting. In order to apply die-casting, the $\mathrm{Al}$ alloys should be verified for die-soldering ability with die steel. It is generally well known that both $\mathrm{Fe}$ and $\mathrm{Mn}$ contents have effects on decreasing die soldering, especially with aluminum alloys containing substantial amounts of Si. However, die soldering has not been widely studied for the low Si aluminum (1.0 2.0wt\%) alloys. Therefore, in this study, an investigation was performed to consider how the soldering phenomena were affected by Fe and Mn contents in low Si aluminum alloys. Each aluminum alloy was melted and held at $680^{\circ} \mathrm{C}$. Then, STD61 substrate was dipped for $2 \mathrm{hr}$ in the melt. The specimens, which were air cooled, were observed using a scanning electron microscope and were line analyzed by an electron probe micro analyzer. The SEM results of the dipping soldering test showed an Al-Fe inter-metallic layer in the microstructure. With increasing Fe content up to $0.35 \%$, the Al-Fe inter-metallic layer became thicker. In Al-1.0\% $\mathrm{Si}$ alloy, the additional content of $\mathrm{Mn}$ also increased the thickness of the inter-metallic layer compared to that in the alloy without Mn. In addition, EPMA analysis showed that $\mathrm{Al}-\mathrm{Fe}$ inter-metallic compounds such as $\mathrm{Al}_{2} \mathrm{Fe}, \mathrm{Al}_{3} \mathrm{Fe}$, and $\mathrm{Al}_{5} \mathrm{Fe}_{2}$ formed in the die soldering layers.
\end{abstract}

Key words die soldering, Al-Si, Fe, Mn, metallic compound.

\section{1. 서 론}

최근 열전도도가 높은 알루미늄 합금을 방열재료로 이 용하는 사례가 증가하고 있다. ${ }^{1-5)}$ 순 알루미늄의 열전도도 는 $20^{\circ} \mathrm{C}$ 에서 약 $204 \mathrm{~W} \cdot \mathrm{m}^{-1} \cdot \mathrm{K}^{-1}$ 로 금, 은, 구리를 제외하 고 금속 중 가장 높은 열전도도를 가지고 있어 ${ }^{6)}$ 방열재 료로 적합하다. 그러나 순 알루미늄은 높은 열전도도에 비 해 강도가 낮아 표면적이 넓은 방열제품의 제조에 어려 움이 있어 미량의 합금원소를 첨가하여 계량한 알루미 늠 합금을 주로 사용하고 있다. ${ }^{7)}$

최근에는 방열재료의 응용분야가 넓어지고 형상이 복 잡해지면서 압출 등과 같은 소성가공으로는 제품 제조에 한계가 있다. 이러한 문제점을 해결하기 위해 다이캐스팅 을 이용한 제조 방법이 연구되고 있으며 다이캐스팅 제 조법을 이용할 경우 복잡한 형상의 제품 제조가 가능해

Corresponding author

E-Mail : qpt146@kitech.re.kr (Y. M. Kim)
지고 대량 생산으로 생산비도 크게 절감할 수 있는 이 점이 있다. 다이캐스팅 적용에 있어 가장 큰 문제점은 알루미늄 용탕과 금형표면에 발생하는 소착이다. 금형표 면의 소착은 제품 외관 품질과 금형의 수명에 악영향을 미치는 원인이 된다. ${ }^{8-10)}$

일반적으로 알루미늄 합금을 다이캐스팅에 적용하기 위 해서는 주조성 확보를 위해 $\mathrm{Si}$ 함량이 $10 \mathrm{wt} \%$ 정도 첨 가된 합금이 주로 사용되나, 높은 열전도도를 얻기 위해 서는 첨가원소를 함량을 줄이는 것이 유리하다. 하지만 앞 서 언급한 바와 같이 순 알루미늄의 경우 높은 열전도 도에 비해 강도가 낮고 금형과의 소착이 일어나기 쉬우 므로 방열재료로 사용하기 위해서는 첨가원소의 양을 조 절하여 적당한 강도와 열전도도를 확보하면서 금형과의 소 착을 해결하여야 한다.

본 연구에서는 첨가원소의 함량이 낮은 방열재료를 개 발하기 위해 $\mathrm{Si}$ 함량이 $1 \sim 2 \mathrm{wt} \%$ 내외인 합금을 제조하 여 첨가원소의 함량에 따른 금형과의 소착 현상을 살펴 보았다. $\mathrm{Si}$ 함량이 낮은 알루미늄 합금의 경우, 다이캐 
스팅 공정에 적용되는 경우가 많지 않고 금형과의 소착 현상에 대한 연구도 거의 이루어지지 않고 있다. 일반 적으로 $\mathrm{Si}$ 함량이 높은 알루미늄 합금은 $\mathrm{Fe}$ 와 $\mathrm{Mn}$ 을 첨 가하면 금형과의 소착에 영향을 주는 것으로 알려져 있 으며, ${ }^{10)}$ 이러한 원소들이 $\mathrm{Si}$ 함량이 낮은 알루미늄 합금 의 경우에는 어떠한 영향을 미치는지 알아보기로 하였다.

\section{2. 실험 방법}

\section{1 실험 재료}

$\mathrm{Al}$ 합금을 제작하기 위해 공업용 순 알루미늄을 흑연 도가니에서 용해시켰다. 용해된 알루미늄 용탕에 $\mathrm{Cu}, \mathrm{Mg}$, $\mathrm{Si}$ 모 합금을 첨가하고 $\mathrm{Fe} \mathrm{ALTAB}$ 을 이용하여 $\mathrm{Fe}$ 의 함 량이 $0.08,0.18,0.28,0.35 \mathrm{wt} \%$ 인 합금을 제조하였다. 또한 $0.35 \mathrm{wt} \% \mathrm{Fe}$ 로 제조된 $\mathrm{Al}$ 합금에 $\mathrm{Al}-60 \mathrm{wt} \% \mathrm{Mn}$ 합 금을 이용하여 $\mathrm{Mn}$ 의 함량이 $0,0.2,0.4,0.8 \mathrm{wt} \%$ 인 알루 미늄 합금을 제조하였다. 제작된 알루미늄 합금의 화학 조성을 Table 1(a), (b)에 나타내었다. 소착실험에 사용된 STD61 시편은 $15 \times 15 \times 3 \mathrm{~mm}$ 로 가공하였고 표면을 $1 \mu \mathrm{m}$ 수준까지 경면 연마하여 준비하였다. 가공한 STD61 시 편의 성분은 Table 1(c)에 나타내었다.

\section{2 용탕 침지실험}

제작된 알루미늄 합금을 각각 $1 \mathrm{~kg}$ 씩 흑연도가니에 담 아 $720^{\circ} \mathrm{C}$ 에서 용해하였다. 알루미늄 합금의 용해가 완료 되면 용탕 온도를 $680^{\circ} \mathrm{C}\left( \pm 10^{\circ} \mathrm{C}\right)$ 로 유지시켰다. 준비된 STD61 시편은 알루미나 도가니에 넣어 용탕에 침지시켰 으며, $680^{\circ} \mathrm{C}$ 에서 2 시간 침지 후 흑연도가니에서 시편을 꺼 내 철판 위에서 공냉시켰다. 알루미늄 합금과 금형강 사

Table 1. Chemical analysis of the Al based alloy and STD61 specimen (wt\%); (a) Al-Si-Fe alloys, (b) Al-Si-Fe-Mn alloys and (c) STD61 steel.

\begin{tabular}{|c|c|c|c|c|c|c|c|}
\hline (a) & $\mathrm{Al}$ & $\mathrm{Si}$ & & $\mathrm{Mg}$ & $\mathrm{Cu}$ & $\mathrm{Fe}$ & $\mathrm{Mn}$ \\
\hline $0.08 \mathrm{Fe}$ & Bal. & 1.57 & & 0.21 & 0.14 & 0.08 & - \\
\hline $0.18 \mathrm{Fe}$ & Bal. & 1.16 & & 0.17 & 0.11 & 0.18 & - \\
\hline $0.28 \mathrm{Fe}$ & Bal. & 1.17 & & 0.19 & 0.10 & 0.28 & - \\
\hline $0.35 \mathrm{Fe}$ & Bal. & 1.14 & & 0.14 & 0.10 & 0.35 & - \\
\hline (b) & $\mathrm{Al}$ & $\mathrm{Si}$ & & $\mathrm{Mg}$ & $\mathrm{Cu}$ & $\mathrm{Fe}$ & $\mathrm{Mn}$ \\
\hline $0 \mathrm{Mn}$ & Bal. & 1.14 & & 0.14 & 0.10 & 0.35 & - \\
\hline $0.2 \mathrm{Mn}$ & Bal. & 1.14 & & 0.14 & 0.10 & 0.35 & 0.21 \\
\hline $0.4 \mathrm{Mn}$ & Bal. & 1.23 & & 0.20 & 0.12 & 0.41 & 0.46 \\
\hline $0.8 \mathrm{Mn}$ & Bal. & 1.37 & & 0.22 & 0.13 & 0.43 & 0.78 \\
\hline (c) & $\mathrm{Fe}$ & $\mathrm{C}$ & $\mathrm{Si}$ & $\mathrm{Mn}$ & $\mathrm{Cr}$ & Mo & $\mathrm{Ni}$ \\
\hline STD61 & Bal. & 0.7 & 0.86 & 0.32 & 4.7 & 1.33 & 0.07 \\
\hline
\end{tabular}

이의 소착층을 관찰하기 위해 시편을 연마하여 $\mathrm{SEM}$ 과 $\mathrm{EDX}$ 를 분석하였다. 그리고 소착층의 전반에 걸친 합금원 소의 분포를 확인하기 위해여 $\mathrm{EPMA}$ 를 이용해 $0.1 \mu \mathrm{m}$ 간 격으로 Line분석을 실시하였다.

\section{3. 결과 및 고찰}

\subsection{Al-Si-Fe계 합금의 소착현상}

$\mathrm{Si}$ 의 함량을 $1 \mathrm{wt} \%$ 내외로 갖는 $\mathrm{Al}-\mathrm{Si}$ 의 합금에서 $\mathrm{Fe}$ 가 소착현상에 미치는 영향을 확인하기 위해 STD61 금형강 을 이용하여 소착실험을 진행하였다. 소착층의 단면을 $\mathrm{FE}-$ $\mathrm{SEM}$ 을 이용하여 관찰한 결과를 Fig. 1에 나타내었으며, $\mathrm{SEM}$ 이미지에서 소착층 두께를 측정한 결과를 Fig. 2에 나타내었다. Fig. 2에서 $\mathrm{Fe}$ 의 함량이 증가함에 따라 소착 층의 두께가 증가하였으며, 4 가지 합금 모두에서 $\mathrm{Al}$ 합금 쪽의 계면이 STD61쪽 보다 굴곡이 심한 것을 알 수 있
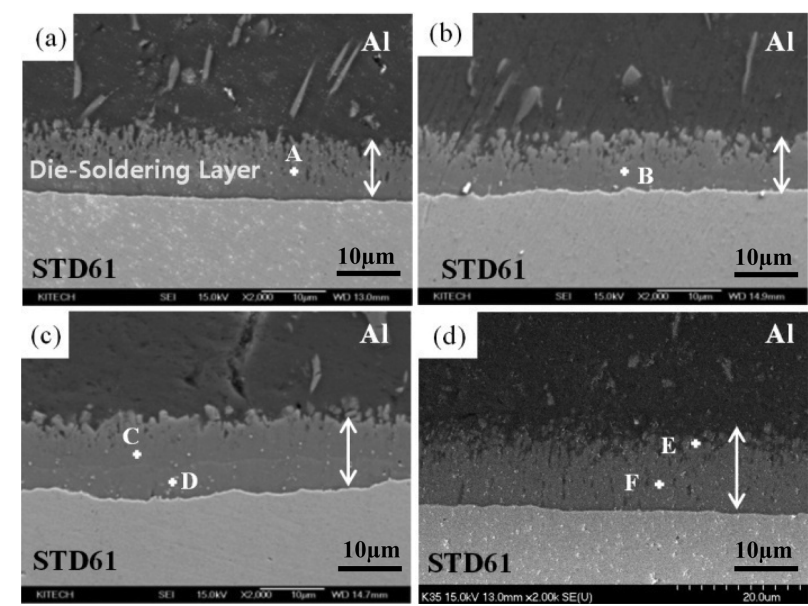

Fig. 1. FE-SEM image of die soldering layer; (a) $0.08 \mathrm{Fe}(\times 2000)$, (b) $0.18 \mathrm{Fe},(c) 0.28 \mathrm{Fe}$ and (d) $0.35 \mathrm{Fe}$.

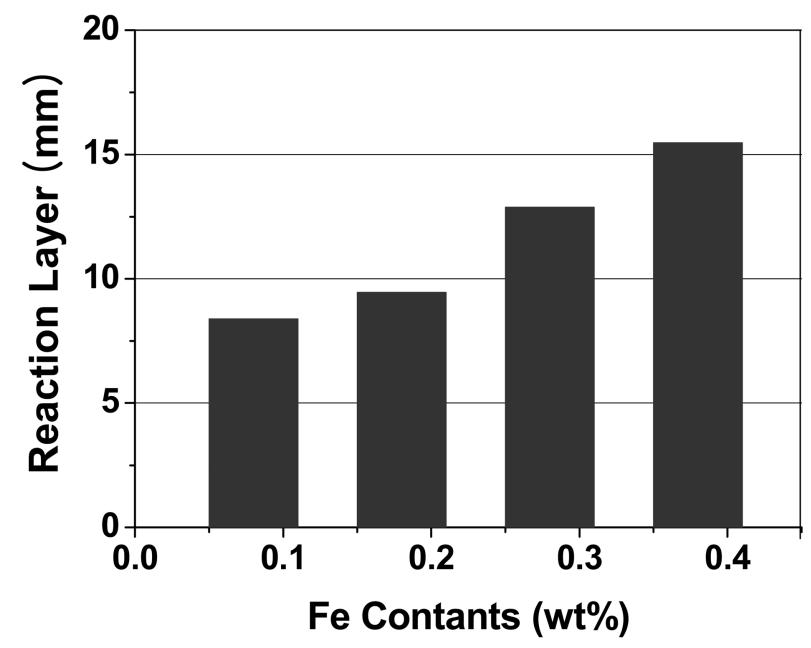

Fig. 2. Thickness of die soldering layers : Al-Si-Fe alloy. 
Table 2. Results of EDX analysis on the die-soldering layers : Al-SiFe alloy (at $\%)$.

\begin{tabular}{ccccccc}
\hline & (a) & (b) & \multicolumn{2}{c}{ (c) } & \multicolumn{2}{c}{ (d) } \\
& A & B & C & D & E & F \\
\hline $\mathrm{Al}$ & 79.24 & 78.21 & 73.82 & 77.86 & 78.09 & 84.11 \\
$\mathrm{Fe}$ & 20.76 & 21.29 & 25.68 & 22.15 & 21.91 & 15.89 \\
\hline
\end{tabular}

었다.

소착층의 화학조성을 알아보기 위해 소착층 위치별 $\mathrm{EDX}$ 분석을 실시하였고, 그 결과를 Table 2에 나타내 었다. $\mathrm{EDX}$ 분석 결과, 소착층은 주로 $\mathrm{Al}-\mathrm{Fe}$ 의 2원계 화 합물을 형성함을 알 수 있었다. 금속간화합물의 성분분 포를 알아보기 위해 EPMA 라인 분석을 실시하였고, 그 결과를 Fig. 3에 나타내었다. EPMA 분석결과, 금형에 가까운 계면에서 $\eta\left(\mathrm{Al}_{5} \mathrm{Fe}_{2}\right)$ 상이 형성되고 반대 방향으로 갈수록 알루미늄 함량이 우세한 $\theta\left(\mathrm{Al}_{3} \mathrm{Fe}\right)$ 상이 형성되어 있음을 알 수 있다. 이러한 결과는 앞서 보고된 연구 결 과 ${ }^{1,49}$ 와 유사하며, 소착층 형성이 $\mathrm{Fe}$ 의 확산과 깊은 연 관이 있음을 유추 할 수 있다. ${ }^{8,9}$

이는 S. Shankar 등이 제시한 것처럼 용탕의 $\mathrm{Fe}$ 함량이 증가됨에 따라 최대 고용도와 알루미늄 용탕 중의 $\mathrm{Fe}$ 농 도 차이가 감소하므로, $\mathrm{Fe}$ 원자 확산의 구동력으로 작용 하는 화학적 포텐셜 기울기가 감소하여 반응층의 두께가 감소되는 것으로 생각된다. ${ }^{11)}$

이외에도 높은 $\mathrm{Si}$ 함량을 갖는 알루미늄 합금의 소착현 상과 $\mathrm{Fe}$ 의 확산속도의 관계를 규명하기 위한 많은 연구

(a)

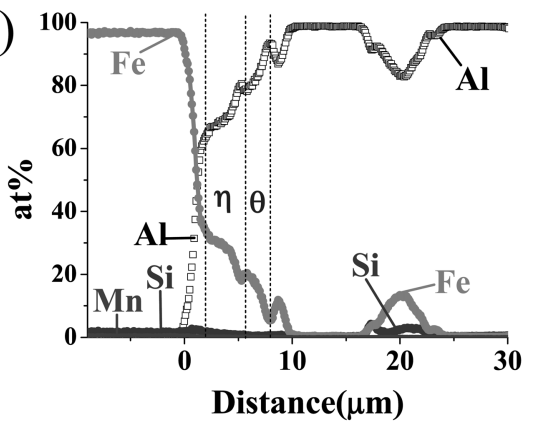

(c)

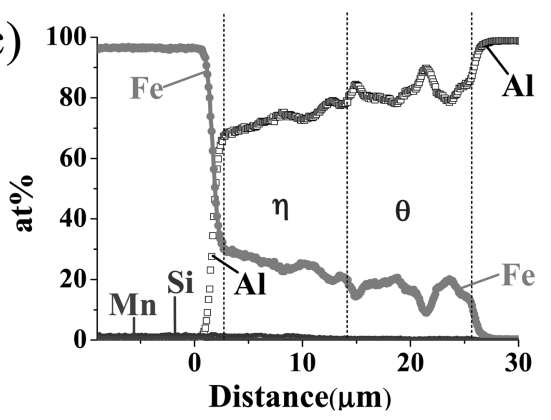

를 참고하였을 때, 알루미늄 합금의 $\mathrm{Fe}$ 함량을 최대 고용 도 만큼 첨가하게 되면 용탕의 고용도에 대한 화학적 포 텐셜의 기울기가 줄어들어 금형에서 확산되는 $\mathrm{Fe}$ 양이 감 소하게 된다. 결과적으로 금형 소착층을 생성하는 $\mathrm{Fe}$ 의 양이 감소되어 소착현상이 억제되는 것이다. ${ }^{10-13,15)}$

위의 결과들을 참고하여 본 연구에서 제작된 알루미늄 합금의 $\mathrm{Fe}$ 고용도를 알아보기 위해 John A. Taylor가 고 안한 $\mathrm{Si}$ 함량에 따른 $\mathrm{Fe}$ 의 고용도를 계산하는 관계식을 인용하였다. ${ }^{16)}$

$$
\mathrm{Fe}_{\text {crit }}(\mathrm{wt} \%) \approx 0.075 \times(\% \mathrm{Si})-0.05
$$

위의 식을 참고하여 계산하였을 때, 본 실험에서 사용 된 $\mathrm{Al}-1 \mathrm{wt} \% \mathrm{Si}$ 합금의 $\mathrm{Fe}$ 고용도는 약 $0.0025 \mathrm{wt} \%$ 이다. 이 는 알루미늄 합금에 첨가된 $\mathrm{Fe}$ 함량보다 적은 양이므로 용탕내의 $\mathrm{Fe}$ 원소들은 용탕에 고용되지 못하고 소착되어 화 합물층을 형성하며 석출되는 것으로 생각된다. 결과적으 로 $\mathrm{Fe}$ 의 함량이 높아질수록 고용되지 못하는 $\mathrm{Fe}$ 의 양이 증가하여 소착층의 두께도 증가하게 되는 원인이 된다.

\subsection{Al-Si-Mn계 합금의 소착현상}

$\mathrm{Fe}$ 와 함께 소착 억제성분으로 알려진 $\mathrm{Mn}$ 의 효과를 알 아보기 위해 Table 1(b)와 같은 Al-Si-Mn합금을 제조하여 소착실험을 실시하였다. 소착층 형성 후 FE-SEM을 이용 하여 관찰한 단면 이미지를 Fig. 4에 나타내었다. Al-Si$\mathrm{Mn}$ 계 합금의 소착층은 $\mathrm{Al}-\mathrm{Si}-\mathrm{Fe}$ 계 합금과 달리 금형강 내
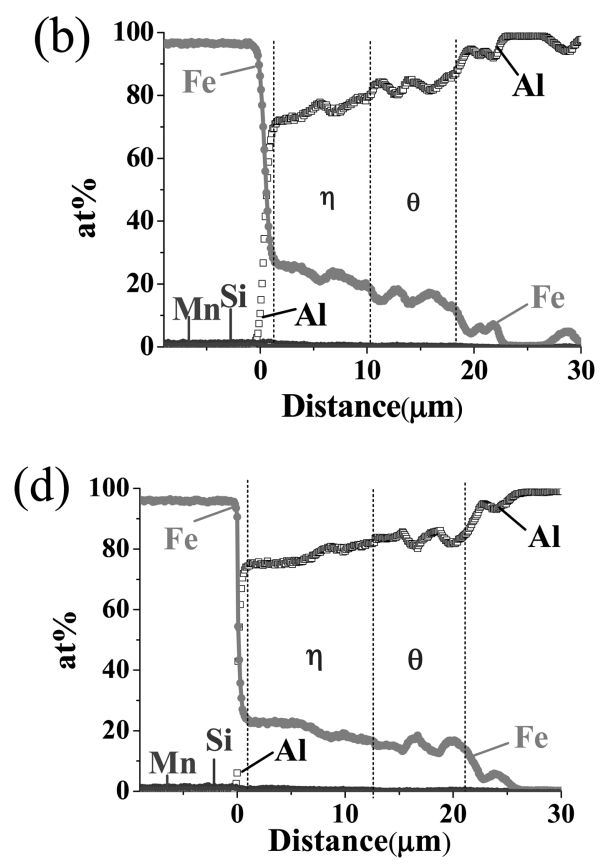

Fig. 3. The result of BSE and EPMA analysis of the soldering layer : (a) $0.08 \mathrm{Fe}$, (b) $0.18 \mathrm{Fe}$, (c) $0.28 \mathrm{Fe}$ and (d) $0.35 \mathrm{Fe}$. 

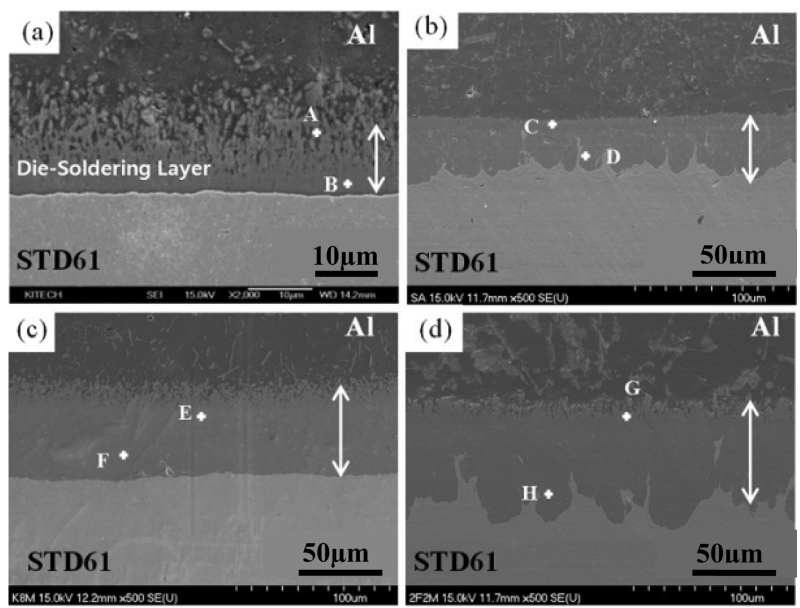

Fig. 4. FE-SEM image of die soldering layers; (a) $0 \mathrm{Mn}(\times 2000)$, (b) $0.2 \mathrm{Mn}(\times 500)$, (c) $0.4 \mathrm{Mn}(\times 500)$ and $(\mathrm{d}) 0.8 \mathrm{Mn}(\times 500)$.

부 방향으로 기둥모양의 형상을 보였다.

FE-SEM이미지를 이용하여 소착층의 두께를 측정한 후 그 결과를 Fig. 5에 나타내었다. 알루미늄 합금의 $\mathrm{Mn}$ 함 량이 증가할수록 소착층의 두께도 증가하였다. 각 소착층

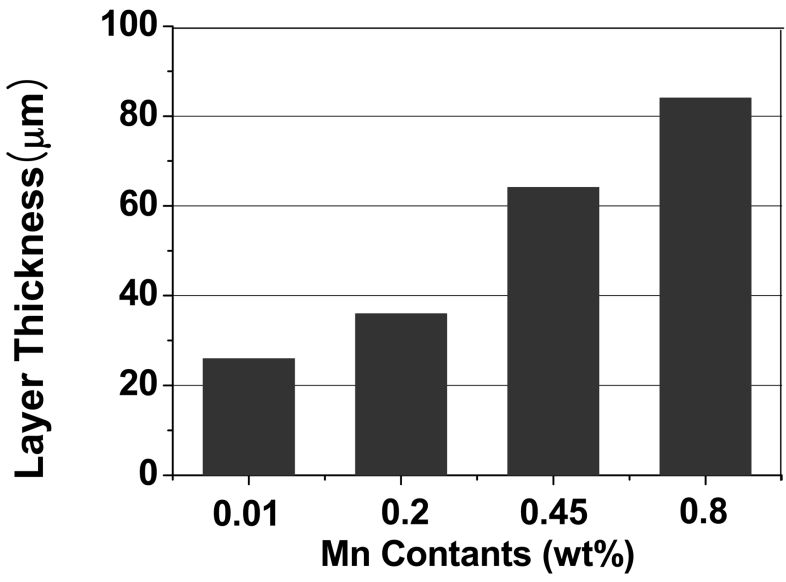

Fig. 5. Thickness of die soldering layers : Al-Si -Fe-Mn alloy.

의 EDX 분석결과, Table 3에 나타낸 바와 같이 대부분 $\mathrm{Al}$ 와 $\mathrm{Fe}$ 로 이루어져 있었으며, 소량의 $\mathrm{Si}$ 가 검출되었다.

소착층이 형성되는 과정에서 성분분포를 알아보기 위해 EPMA 라인분석을 실시하였고, 그 결과를 Fig. 6에 나타 내었다. Fig. 6에 나타낸 바와 같이 소착층은 $\zeta\left(\mathrm{Al}_{2} \mathrm{Fe}\right)$,

Table 3. Results of EDX analysis on the die-soldering layers : Al-Si-Fe-Mn alloy (at\%).

\begin{tabular}{cccccccccc}
\hline & & (a) & & \multicolumn{2}{c}{ (b) } & \multicolumn{2}{c}{ (c) } & & (d) \\
& $\mathrm{A}$ & $\mathrm{B}$ & $\mathrm{C}$ & $\mathrm{D}$ & $\mathrm{E}$ & $\mathrm{F}$ & $\mathrm{G}$ & $\mathrm{H}$ \\
\hline $\mathrm{Al}$ & 78.09 & 84.11 & 76.51 & 73.64 & 73.6 & 70.46 & 75.49 & 72.95 \\
$\mathrm{Fe}$ & 21.91 & 15.89 & 23.49 & 26.36 & 25.05 & 27.6 & 21.40 & 24.84 \\
$\mathrm{Si}$ & - & - & - & - & 1.35 & 1.94 & 3.11 & 2.21 \\
\hline
\end{tabular}

(a)

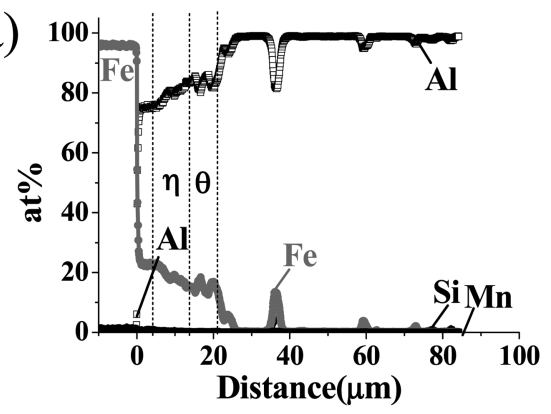

(c)

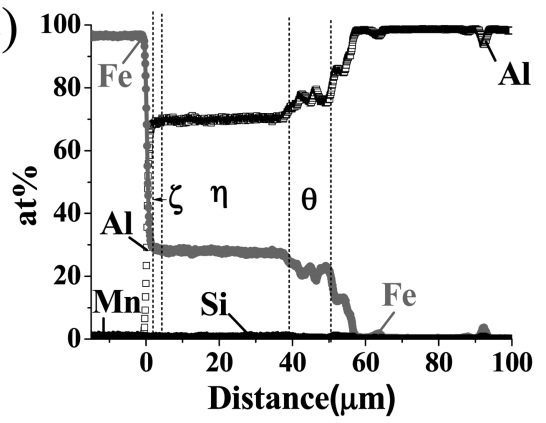

(b)

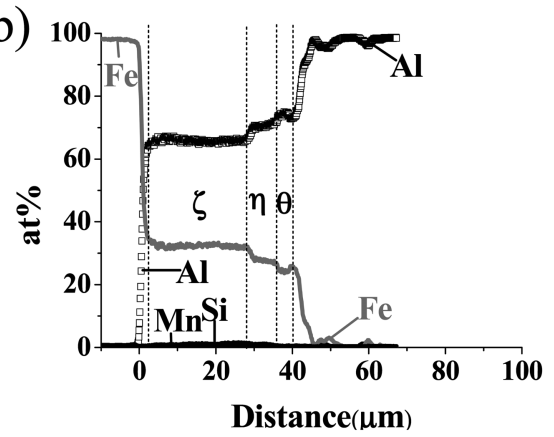

(d)

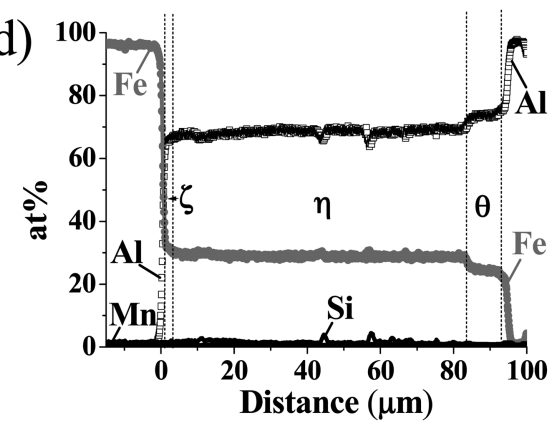

Fig. 6. The result of BSE and EPMA analysis of the soldering layer: (a) $0 \mathrm{Mn}$ (b) $0.2 \mathrm{Mn}$, (c) $0.4 \mathrm{Mn}$ and (d) $0.8 \mathrm{Mn}$. 
$\eta\left(\mathrm{Al}_{5} \mathrm{Fe}_{2}\right), \theta\left(\mathrm{Al}_{3} \mathrm{Fe}\right)$ 상과 같은 $\mathrm{Al}-\mathrm{Fe}$ 2원계 금속간 화합물 로 형성되어 있음을 알 수 있다. 앞의 세가지 상 중 $\eta$ 상 은 $\mathrm{Al}-\mathrm{Fe} 2$ 원계 화합물의 대표적인 상으로, c축 방향의 기 둥형태로 성장하는 것으로 알려져 있으며, ${ }^{14)} \mathrm{Fig} .4(\mathrm{~b})$ 에 서도 이와 비슷한 형상의 소착층이 발견되었다.

소착층의 두께가 $\mathrm{Mn}$ 의 첨가와 함께 증가하는 현상은 알 루미늄 용탕에 첨가된 $\mathrm{Mn}$ 의 영향으로 생각된다. $\mathrm{Mn}$ 원소 의 원자번호는 25 번으로 원자 번호 26 번을 갖는 $\mathrm{Fe}$ 와 외 각전자수가 비슷하고, 두 원소의 원자 반경 또한 $1.24 \AA$ 와 $0.112 \AA$ 으로 약 $11 \%$ 의 차이를 갖고 있어 치환형 원소 의 조건을 충족한다. ${ }^{18)}$ Donnadieu 등의 연구에서도 $\mathrm{Mn}$ 이 $\mathrm{Fe}$ 의 치환형 원소로 작용하여 $\mathrm{Al}-\mathrm{Fe}$ 나 $\mathrm{Al}-\mathrm{Fe}-\mathrm{Si}$ 의 금속간 화합물 대신 $\mathrm{Al}-(\mathrm{Fe}, \mathrm{Mn})$ 또는 $\mathrm{Al}-(\mathrm{Fe}, \mathrm{Mn})-\mathrm{Si}$ 를 형성한다고 보고하고 있다. ${ }^{17,19)}$

$\mathrm{Mn}$ 은 $\mathrm{Al}$ 합금내에 거의 고용되지 않기 때문에 ${ }^{7}$ 대부 분 $\mathrm{Fe}$ 의 치환형 원소로 거동하게 된다. 이 때 $\mathrm{Mn}$ 이 $\mathrm{Fe}$ 의 치환형 원소로 거동하게 되면 $\mathrm{Fe}$ 의 고용도에 비해 과 도한 $\mathrm{Fe}(\mathrm{Mn})$ 이 용탕 내에 존재하게 되고, 결과적으로는 금속간 화합물 형성하는데 기여하게 될 것이다. 그리고 그 결과 $\mathrm{Mn}$ 역시 $\mathrm{Fe}$ 와 마찬가지로 용탕내 첨가량이 증 가할수록 알루미늄 합금과 금형강 사이의 소착층의 두 께가 증가하게 된다. 이러한 반응의 근거로, Fig. 6(b), (c), (d)에서 소착층 내부에서 미량의 $\mathrm{Mn}$ 이 검출된 것을 확인 할 수 있다. 확인된 $\mathrm{Mn}$ 의 양은 모 합금에 첨가한 양보다 많았으며, 금형강과 알루미늄 합금에서 확산 된 것으로 생각된다.

\section{4. 결 론}

$\mathrm{Si}$ 함량이 낮은 $\mathrm{Al}-\mathrm{Si}$ 합금에 첨가된 $\mathrm{Fe}$ 및 $\mathrm{Mn}$ 이 알루 미늄 용탕과 STD61 금형강 사이의 계면에서 소착현상에 어떠한 영향을 미치는지 알아보았다.

$\mathrm{Al}-\mathrm{Si}$ 의 합금에 $\mathrm{Fe}$ 함량을 증가시켜 STD61과의 소착현 상을 관찰한 결과 $\mathrm{Fe}$ 의 함량이 증가할수록 소착층의 두 께가 증가하였다. 이는 소량의 $\mathrm{Si}$ 를 첨가한 $\mathrm{Al}$ 합금의 내 $\mathrm{Fe}$ 고용도가 $0.01 \mathrm{wt} \%$ 이하로 용탕 내부에 존재하는 $\mathrm{Fe}$ 가 고 용되지 못하고 소착층을 형성하기 때문으로 생각된다. 그 결과 $\mathrm{Fe}$ 의 첨가량이 증가할수록 소착층의 두께도 증가하 는 것으로 나타났다.

또한 $\mathrm{Al}-\mathrm{Si}-\mathrm{Fe}$ 의 합금에 $\mathrm{Mn}$ 의 성분을 증가시켜 STD61 과의 소착현상을 관찰 한 결과 $\mathrm{Mn}$ 또한 첨가량이 증가 할수록 소착층의 두께가 증가하는 것을 확인하였다. 이는 $\mathrm{Mn}$ 원소가 $\mathrm{Fe}$ 의 치환형 원소로 작용하여 소착층의 생성 에 참여하였기 때문이다.

\section{참 고 문 헌}

1. S. C. Lim, M. H. Lee and K. M. Kang, Kor. J. Mater. Res., 15(12), 829 (2005) (in Korean).

2. W. H. Hsieh, J. Y. Wu, W. H. Shih and W. C. Chiu, Int. J. Heat Mass Tran., 47(23), 5149 (2004).

3. W. H. Shih, W. C. Chiu and W. H. Hsieh, J. Heat Tran., 128, 530 (2006).

4. S. Y. Kim, J. M. Koo and A. V. Kuznetsov, Numer. Heat Tran., 40(1), 21 (2001).

5. S. Y. Kim, J. W. Paek and B. H. Kang, IEEE Trans. Compon. Packag. Tech., 26(1), 262 (2003).

6. E. A. Brandes and G. B. Brook, Smithells Metals Reference Book, $7^{\text {th }}$ ed, 14.11 (14.3b), Butterworth-Heine mann, UK (1992).

7. Microstructures and Properties of Aluminum alloys, (in Japanese), p. 171-236, Japan Institute of Light Metals, Japan (1991).

8. S. Shankar and D. Apelian, Metall. Mater. Trans. B, 33, 465 (2002).

9. H. R. Shahverdi, M. R. Ghomashchi, S. Shabestari and J. Hejazi, J. Mater. Process. Tech., 124, 345 (2002).

10. H. -J. Kim, C. -M. Cho, C. -Y. Jeong, J. Korean Foundry. Soc., 29(4), 24 (2009) (in Korean).

11. S. Shankar and D. Apelian, J. Met, 54(8), 47 (2002).

12. E. K. Holz, in Proceedings of the 7th SDCE International Die Casting Congress (Chicago, Illinois, October, 1972), p.4372.

13. A. Kopper and R. Donahue, Light Met., 2006, 801-805 (2006).

14. H. Springer, A. Kostka, E. J. Payton, D. Raabe, A. Kaysser-Pyzalla and G. Eggeler, Acta Mater. 59, 1586 (2011).

15. M. M. Makhlouf and D Apelian, Casting Characteristics of Aluminum Die Casting Alloys, p. 9-20, The Advanced Casting Research Center, USA (2002).

16. J. A. Taylor, G. B. Schaffer and D. H. St. John, Metall. Mater. Trans., 30, 1651 (1999).

17. N. C. W. Kuijpers, F. J. Vermolen, C. Vuik, P. T. G. Koenis, K. E. Nilsen and S. van der Zwaag, Mater. Sci. Eng., 394, 9 (2005).

18. J. F. Shackelfold, Introduction to Materials Science for Engineers, $3^{\text {rd }}$ ed., App.2, Macmillan, USA (1995).

19. N. C. W Kuijpers, W. H. Kool, P. T. G. Koenis, K. E. Nilsen, I. Todd and S. van der Zwaag, Mater. Char., 49, 409 (2003). 